DOI https://doi.org/10.29303/baktinusa.v2i1: April 2021.26

\title{
PROGRAM BERSIH SAMPAH UNTUK PENDUDUK Di PESISIR PANTAI DESA BATU NAMPAR SELATAN KABUPATEN LOMBOK TIMUR
}

\author{
Made Sutha Yadnya1; Sultan'; I Made Ginarsa1; I Made Ari Nrartha'; \\ Agung Budi Muljono'; Sudi Mariyanto Al Sasongko'; Desi Widianty ${ }^{2}$ \\ msyadnya@unram.ac.id ${ }^{1}$ \\ 1Jurusan Teknik Elektro, Fakultas Teknik, Universitas Mataram \\ 2Jurusan Teknik Sipil, Fakultas Teknik, Universitas Mataram
}

\begin{abstract}
ABSTRAK
Manusia merupakan mahluk individu dan mahluk sosial. Salah satu fungsinya adalah menjaga kebersihan. Kondisi terjadi sebaliknya penduduk di daerah pesisir Desa Batu Nampar yang mempunyai tingkat kebersihan yang rendah akibat sampah masih berhamburan dan berserakan sebelum adanya pengabdian masyarakat. Langkah yang diambil untuk mengatasi hal tersebut adalah membuat bak sampah ditempat yang tepat. Pengabdian ini juga untuk membentuk pola pikir masyarakat agar dapat mengolah sampah menjadi hal yang bermanfaat serta menghasilkan uang.Tim pengabdian terhadap masyarakat turun langsung lewat program mandiri dari Universitas Mataram khusus Fakultas Teknik turun langsung ke lapangan mengatasi masalah ini.Sehingga terdapat bak penampungan sampah serta pengolahan sampah menjadi kompos yang dapat dijual sebagai pupuk.
\end{abstract}

Kata Kunci : kebersihan, sampah, kompos

\section{PENDAHULUAN}

Pada bulan Oktober sampai Desember 2019 pengabdian ini dilaksananakan di Desa Batu Nampar Selatan. Posisi Desa Batu Nampar Selatan berada dipesisir pantai dengan mayoritas matapecarian sebagai nelayan, merupakan desa ini memiliki sumber daya alam seperti laut, yang dapat dimanfaatkan oleh masyarakat dalam kegiatan perikanan.Kegiatan perikanan mempunyai effek positif maupun negative, laut sebagai lahan matapencarian dimanfaatkan masyarakat sekitar sebagai sumbet alam yang dapat diperbaharui ingin selalu menjaga agar laut tetap alami yang ada diwilayah tersebut.Effek negative yang terjadi adalah masalah kebersihan (hygienist) yang kurang terjamin.sehingga masyarakat yang tinggal di sekitaran desa tersebut sering mengalami terjakit penyakit diare, tipus, malaria, demam berdarah dan berbagai macam penyakit berbahaya lainnya. Pada Desa Batu Nampar ini memiliki toleransi sosial yang tinggi dan dapat menjalin silahturasmi antara pemerintah dan penduduk namun perlu didtingkatkan khusus pada kebersihan ${ }^{[1]}$ (Kepadatan penduduk dengan konsumsi tinggi menyebabkan sampah yang dihasilkan tiap hari semakin banyak.Sampah menjadi problema masalah yang harus diatasi dengan pengolahan dan kesadaran terhadap sampah.Faktor penyebab utamanya adalah kesadaran masyarakat yang sangat kurang dan belum adanya tempat pembuangan sampah akhir. Salah satu hal yang harus dipenuhi dan ditaati adalah masyarakat memutuskan membuang sampah di pinggir pantai bahkan ke sungai.Akumulasi keberadaan sampah di pantai dan laut membuat acaman terhadap ekosistem kehidupan manusia serta pencemaran lingkungan. Keinginan memsejahterakan diri dan keluarga selalu dibangkitkan, salah satu cara adalah mendapatkan pengasilan yang layak. $\mathrm{Bi}$ sisi lain anak- anak yang bertujuan untuk meningkatkan Kepercayaan diri anak-anak dan mendidik tentang moral serta ahlak, karena di desa Batu Nampar Selatan sendiri terdapat anakanak yang rata- rata ditinggal oleh orang tuanya bekerja diluar negri menjadi TKW dan TKI sehingga anak- anak memiliki kebiasaan yang kurang baik seperti berkata kasar, menonton hal yang tidak sesuai dengan umur mereka serta mereka, dan bisa berdampak buruk bagi pergaulan mereka ${ }^{[5]}$.. Upaya untuk mengatasi kejadian seperti ini adalah membuka lapangan kerja salah satunya memberikan lapangan kerja sebagai pembersih sampah, pengangkut 
sampah, pendaur ulang sampah[6]. Sosialisasi dan membangun koneksi yang baik dengan perangkat desa dan masyarakat sekitar. Penyusunan program kerja seharusnya didiskusikan terlebih dahulu bersama Masyarakat desa agar pelaksanaannya tepat sasaran dan dengan menyusun jadwal kegiatan yang tepat dan jelas merupakan kunci penting dalam melaksanakan program kerja, sehingga pelaksanaannya nanti dapat terlaksana dengan lancar dan sesuai dengan rencana. Potensi dan permasalahan Desa Batu Nampar Selatan adalah mengenai kebersihan terutama dalam aktivitas pembuangan dan pengolahan sampah perlu di apliksikan dan dikaji secara nyata. Air Bersih di Desa Batu Nampar Selatan sudah disediakan terlebih dahulu dalam kegaitan sebelum melaksanakan kegiatan pengabdian ini ${ }^{[3]}$. Pengabdian ini juga dibantu oleh mahasiswa KKN Tematik Universitas Mataram [2].

\section{METODE PELAKSANAAN}

Memberikan Sebagian besar penduduk di Desa Batu Nampar Selatan menggantungkan hidupnya pada laut, hampir semua pemuda dan orang tua laki-laki melaut mencari ikan sebagai seorang nelayan.Para nelayan desa batu nampar selatan menjual hasil tangkapannya di Pasar Tanjung luar dan keluar pulau Lombok. Terlepas dari mata pencaharian utama sebagai nelayan, warga desa batu nampar selatan juga memiliki beberapa aktivitas yang biasa dilakukan seperti:

Menciro adalah aktivitas yang biasa dilakukan di pagi hari oleh warga sekitar untuk menunggu para nelayan yang pulang menangkap ikan. Masyarakat yang melakukan aktivitas menciro ini akan diberikan sebagian hasil tangkapannya yang berupa ikan atau cumi-cumi. Kegiatan menciro rutin dilalukan setiap pukul 6-7 pagi di desa batu nampar selatan.Selain kegiatan rutin setiap pagi, menciro juga biasa dilakukan ditengah laut diantara para nelayan yang mendapatkan tangkapan sedikit.

Tradisi tersebut lahir karena sifat kekeluargaan dan kebersamaan yang kental diantara mereka.Hal ini dilakukan sejak jaman nenek moyang mereka. Masyarakat melakukannya sambil duduk membawa wadah dipesisir pantai dan menunggu satu demi satu sampan yang kembali mencari ikan. Warga yang melakukan menciro lebih banyak wanita dan ibu-ibu dari pada laki-laki.

Masker yang terbuat dari bahan-bahan alami menjadi ciri khas tersendiri di Desa Batu Nampar Selatan, selain itu bahannya juga sangat mudah didapatkan seperti daun sirih, buah pinang dan beras yang sudah direndam sebentar. Masker ini dipercaya sebagai pelindung wajah dari sinar matahari yang menyengat dan untuk melembutkan wajah.Tak hanya ibu-ibu yang menggunakan masker ini, banyak juga remaja desa yang menggunakannya. Konon katanya masker ini membuat wanita Desa batu nampar selatan menjadi lebih awet muda

Mada' merupakan kegiatan mencari kerang pantai yang sedang surut.Masyarakat di Desa Batu Nampar Selatan biasanya melakukan mada' di pasir panjang pada sore hari.Pemilihan waktu di sore hari dikarenakan pada sore hari air laut biasanya surut dan membentuk pasir timbul yang panjang.Alat yang digunakan untuk melakukan mada' tidak terlalu banyak, hanya ember dan benda tajam seperti pisau atau sabit. Mada' bisa dibilang pekerjaan susah susah gampang karena jika tidak terbiasa makan akan kesulitan untuk menemukan kerang yang tertimbun didalam pasir. Cara melakukan mada' yaitu dengan mengais-ngais pasir menggunakan pisau atau benda tajam lainnya untuk menemukan kerang.Kerang biasanya ada di dalam pasir dan oleh karena itu kita perlu mengais pasir untuk menemukannya. Kerang yang biasanya didapat yaitu base, kremis, kakalo, dan blida sebutan jenis-jenis kerang di Desa Batu Nampar Selatan. Kerang yang didapat biasanya dimakan ataupun dijual. Kerang yang dijual biasanya dijual langsung tanpa diolah dengan harga Rp30.000.- per ember.

Karena kegiatan tersebut di atas sering berdapak buruk pada terjadinya sampah yang menumpuk di sembarang tempat. Tim mengabdian terhadap masyarakat melakukan pemberikan sosialisasi kepada masyarakat untuk mengoptimalkan keberadaan sarana penyediaan air bersih dan sanitasi lingkungaan, serta sosialisasi pengolahan sampah. Mempererat silaturahmi antara pemuda dan atau masyarakat, meningkatkan partisipasi masyarakat dalam mengatasi permasalahan desa, pembangunan dan perbaikan infrastruktur yang diperlukan desa, serta meningkatkan kreatifitas masyarakat dalam menata desa bersih dan sehat.

\section{HASIL DAN PEMBAHASAN KEGIATAN}


Kesadaran masyarakat mengenai kebersihan lingkungan masih terbilang kurang, terlihat dari masih banyaknya sampah bertebaran di sepanjang pantai, mulai dari sampah organik hingga sampah nonorganik.

Program yang dilaksana selama pengabdaian yang pertama adalah membuat bak samapah pada tempat yang mudah dicapai oleh penduduk serta pengunjung pantai sehingga dapat meminimalisasi untuk buang sampah sembarangan di pantai ataupun sungai, ini sesuai dengan Gambar 1. Pembuatan bak sampah secara bersama-sama dengan masyarakat dan mahasiswa. Setelah bak sampah ada serta dikumpulkan sesuai bentuk sampah organik maupun non organik supaya bisa diolah maupun di daur ulang. Pemilihan sampah olah ibu rumah tangga dan anaknya dengan sadar karena memiliki nilai ekonomis yang dapat menunjang penghasilan, sesuai dengan Gambar 2.

Kurangnya kesadaran masyarakat mengenai sampah membuat mereka membuang sampah dilaut. Hal itu terlihat karena banyak sekali sampah yang ada dipesisir pantai ketika mengelilingi beberapa dusun yang letaknya di pinggir pantai. Sampah tersebut menumpuk dan mengalir sampai ke tengah laut. Pemerintah desa setempat kini telah mengupayakan untuk membuat beberapa tempat penampungan sampah sementara di sepanjang pantai. Hal tersebut diharapkan untuk mengurangi jumlah sampah yang semakin hari semakin menumpuk sepanjang pantai Batu Nampar selatan.

Desa Batu Nampar Selatan yaitu lebih aktif dalam bersosialisasi dan membangun koneksi yang baik dengan perangkat desa dan masyarakat sekitar. Penyusunan program kerja didiskusikan bersama bersama masyarakat desa agar pelaksanaannya tepat sasaran dan dengan menyusun jadwal kegiatan yang tepat dan jelas merupakan kunci penting dalam melaksanakan program kerja, sehingga pelaksanaannya nanti dapat terlaksana dengan lancar dan sesuai dengan rencana. Penempatan bak sampah yang strategis untuk mudah dicapai utamanya di pesisirpantai.

Pemberdayaan dengan slogan "Bersih Pangkal Sehat " harus dikumandangkan dari sejak anak-anak sampai dewasa agar kesadaran tumbuh dari dalam hati sehingga menjaga kebersihan merupakan kebiasaan dan dapat ,menjaga lingkungan dengan baik.

\section{KESIMPULAN}

Pembuatan tempat penampungan sampah serta pemilahan sampah organik maupun non organik dilakukan agar dapat diolah dengan cepat.Untuk yang non organik dikumpulkan untuk didaur ulang, apabila organik disediakan lahan untuk ditanam.Sehingga dapat dihasilkan bak penampungan sampah serta pengolahan sampah menjadi kompos yang dapat dijual sebagai pupuk.

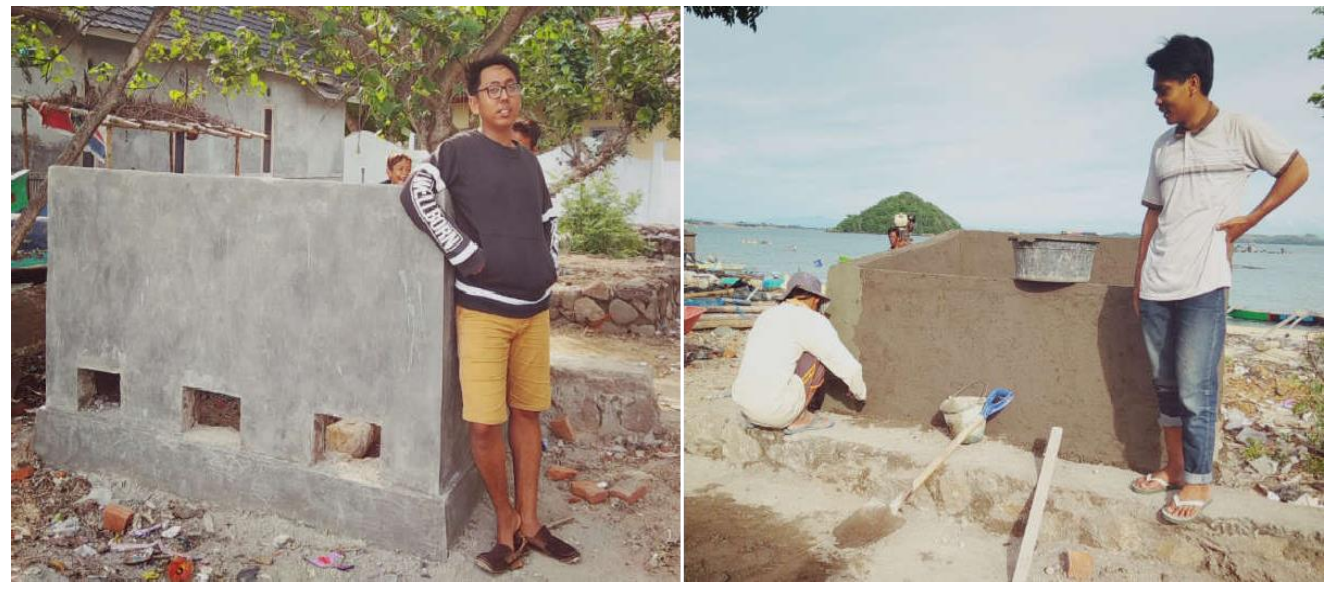

Gambar 1. Proses pembutan model bak sampah sebelum dipasang 


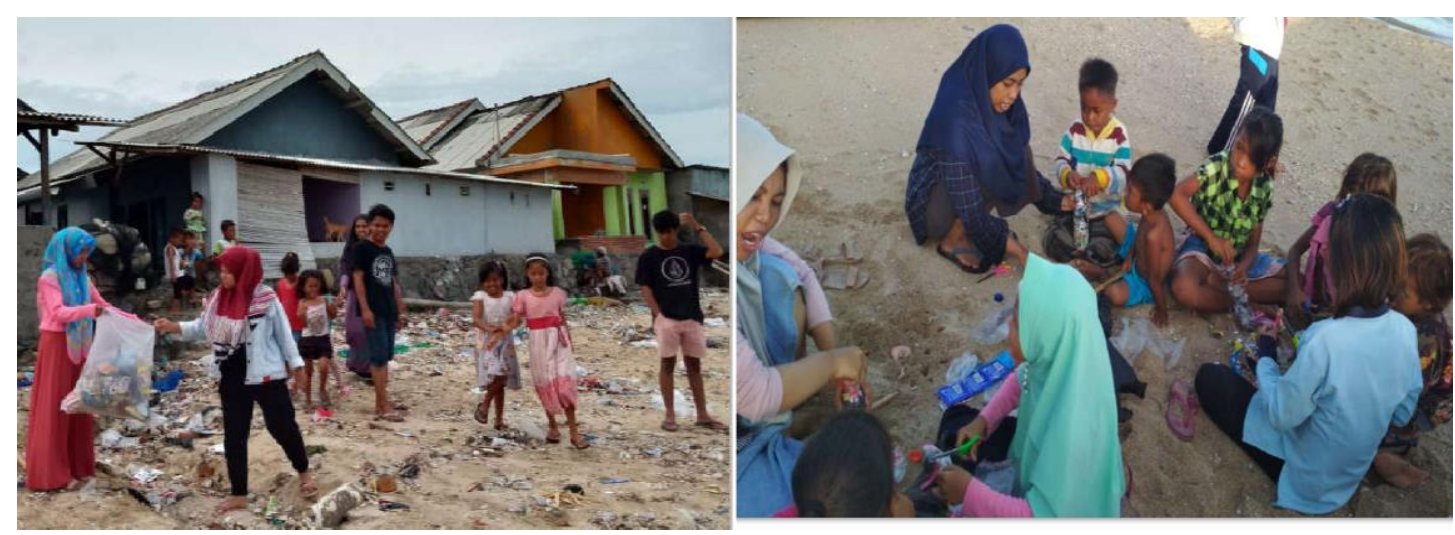

Gambar 2. Proses pengambilan sampah dan pemilahan sampah yang dapat dijual.

\section{UCAPAN TERIMA KASIH}

Semoga makalah ini dapat inspirassi dari kegiatan-kegiatan pengabdian pada masyarakat serta diucapkan terima kasih diucapkan kepada Peserta KKN Universitas Mataram dibawah bimbingan Pak Sultan di Desa Batu Nampar yang memberikan banyak data. Pembiayaan untuk publikasi ini sepenuhnya menggunakan dana mandiri yang dikumpukan dari setoran setiap anggota pengabdian pada masyarakat.

\section{DAFTAR PUSTAKA}

[1] Rasuli.M. 2018. Profil Desa Batunampar Selatan. Jerowaru: Kantor Desa Batu Nampar Selatan

[2] Laporan KKN Tematik, (2020)" Optimalisasi Penyediaan Air Minum Dan Sanitasi Lingkungan Melalui Peningkatan Partisipasi Masyarakat Di Desa Batu Nampar Selatan Kecamatan Jerowaru Kabupaten Lombok Timur " Universitas Mataram 13 Februari 2020.

[3] Yadnya M.S, Sultan, I Made Ginarsa , I Made Ari Nrartha, Desi Widianty., (2020) "Program Pipanisasi Air Tawar Di Daerah Pesisir Pantai Khusus Untuk Penduduk Desa Batu Nampar Selatan Kecamatan Jerowaru Kabupaten Lombok Timur" Jurnal Abdi Insani Universitas Mataram.

[4] Yadnya M.S . Tahmid A, Zainuddin A. ZubaidahT. Kanata B. Paniran (2020), " Program Air Siap Minum Untuk Siswa dan Penduduk Terdampak Gempa di Sekolah Dasar Nengeri 3 Malaka Teluk Nara Pemenang, Kabupaten Lombok Utara" . Jurnal Gema Ngabdi LPPM Universitas Mataram. DOI: https://doi.org/10.29303/jgn.v2i1.71.

[5] BPBD, (2018), "Laporan CNN Indonesia Selasa, 07/08/2018 18:59 WIB" Berita langsung diakses tanggal 24 April 2019.

[6] Menteri Kesehatan RI, (2017), Peraturan Menteri Kesehatan Republik Indonesia Nomor 32 TAHUN 2017, diakses tanggal 26 April 2019. 